\title{
Separation Cum Pre-Concentration Technique for Determination of Uranium in Sea, Brine and Ground Water at Nano to Sub nanogram Levels
}

\author{
Leela Gopal', V. V. Hanuman, G. Chakrapani \\ Atomic Minerals Directorate for Exploration and Research, DAE, Begumpet, Hyderabad, India \\ *Corresponding Author : leelagopal.amd@gov.in
}

\begin{abstract}
Investigations were carried out for separation/pre concentration of uranium from aqueous solutions of different TDS using Powdered Activated Carbon (PAC). Parameters like amount of PAC, contact time, $\mathrm{pH}$, volume of solutions and reagents for desorption were optimized. The sorption of uranium is more than $95 \%$ at $\mathrm{pH} 4-5$ using 0.5 gram PAC with a contact time of 10 minutes. The sorbed uranium on PAC is recovered using $0.8 \mathrm{~N}$ $\mathrm{HNO}_{3}$ and determined by LED Fluorimetry. Method was successfully applied to ground water, sea water and brine water. Methodology is simple, selective, cost effective with minimal skills. RSD of the method varies $\pm 6-$ $14 \%$.
\end{abstract}

Keywords : Uranium, PAC, Separation, Pre Concentration, Ground Water, Sea Water, Brine Water

\section{INTRODUCTION}

Uranium (U) gets leached in to ground water or surface waters through rocks, soils, agricultural inputs etc. Similar to many other heavy metals, uranium is also toxic to humans and animals. The most toxicological end point is damage to the kidney through chemical interactions [1]. Various geochemical surveys are in vogue in order to find out economically viable uranium deposits. Hydrogeochemical survey is one of the most widely used exploration techniques, to locate buried uranium deposits in soil-covered areas. It also helps in narrowing down the target areas and to delineate anomalous zones favorable for uranium. Due to the limitation of the techniques available for quantifying uranium below $1 \mathrm{ng} / \mathrm{mL}$, some of the areas go uninterpreted which may be the promising areas for the uranium exploration program. Hence, groundwater samples require to be analyzed down to 0.01 $\mathrm{ng} / \mathrm{mL}$ for a meaningful interpretation of the data which demands pre-concentration prior to analysis. In this study, the authors developed a simple separation and pre-concentration method based on the sorption of uranium using powdered activated carbon (PAC), resulting in enrichment factor of 200 for below $1 \mathrm{ng} / \mathrm{mL}$ uranium values in ground-water samples. Uranium separated prior to determination in high Total Dissolved Solids (TDS), sea and brine water samples.

The concentration of uranium $(\mathrm{U})$ in ground, sea, and brine water is at ppb levels. There are several techniques available for the determination of uranium at trace levels [2-6] but they are not sufficiently sensitive at sub ppm and ppb levels and could not be employed as field techniques. Even though, inductively coupled plasma quadrupole mass spectrometry (ICP-QMS) is capable of uranium determination at ppb level, it is sensitive to the sample matrix. Samples like sea, brine, and high TDS ground-water samples cannot be feed to the ICP-MS 
directly. Hence it requires a separation step [7] prior to uranium determination and thus is limited for use in field applications. Robbins et al. [8] reported a field procedure for the determination of uranium in natural water by laser-induced fluorimetry. The method is rapid, does not involve separation, and can be directly applied as a field technique. Though this technique is capable of determining uranium at $\mathrm{ppb}$ levels it suffers interference from dissolved organic matter, manganese, iron, and high TDS. The phosphate salts used as fluorescence enhancing reagents cannot tolerate high concentrations of calcium, magnesium and background electrolytes which form insoluble phosphates and leads to erroneous values. Sea water and brine water contains high concentrations of chloride, which acts as a strong quencher, reduces uranium fluorescence intensity, and even the standard additions method is also not feasible for direct determination. In addition to chloride, high TDS also limits direct determination of uranium due to physical interference of calcium and magnesium which forms insoluble phosphates with fluorescence enhancing buffer, hence, it needs to be separated from the matrix. In this context, the authors developed a simple rapid simultaneous separation and pre-concentration method for the determination of traces of uranium in high TDS natural waters, sea, and brine water. Uranium is commonly separated and pre-concentrated by precipitation methods [9-11], ion exchange and chromatographic meth $\neg$ ods [12-15], extraction methods [16-19], and sorption methods [20-22]. Each of these methods has merits and limitations in their application. Of these methods, the adsorption methods are front runners for the separation and preconcentration of uranium in natural ground, sea, and brine waters to determine at nano to sub nano gram levels because of their simplicity and selectivity. Various adsorbents such as olivine rock [23], coir pith [24], kaolinite [25], bio mass [26], goethite [27], modified rice stem [28], and activated carbon [29-30] are used by many researchers for either removal or separation of uranium. Activated carbon is the most effective and economic material because of its stability, simplicity, selectivity, easy availability, regeneration, and re-use. Mellah et al [29] used granular activated carbon for removal of uranium at pH 3 with a contact time of 240 minutes. Karadeniz et al [30] carried out investigations on the adsorption of uranium using activated carbon, and the optimum parameters were $\mathrm{pH} 3$ with a shaking time of 3 hours. In both of these cases, the $\mathrm{pH}$ is acidic and requires a higher contact time which limits their application to an exploration program where a large number of ground-water samples used for exploration studies. Hence, these authors tried to apply powdered activated carbon, for the simultaneous separation and preconcentration of uranium at a near to neutral $\mathrm{pH}$ with less contact time. Earlier, some authors used the powdered activated carbone (PAC) extensively for the pre-concentration of transition metals, rare earth elements and platinum group elements (PGE), and the PAC is further extended for pre-concentration of uranium and removal of uranium [31], [32]. The most common salts of uranium in natural waters are carbonates, chlorides, sulfates, phosphates, nitrates, etc. Uranium forms complexes with chlorides and sulfates which are predominant anions in ground, brine, sea-waters, and gets sorbed on powdered activated carbon. In carbonate-bearing water and seawater, uranium forms a strong complex with carbonate and the predominant species is $\mathrm{UO}_{2}\left(\mathrm{CO}_{3}\right)_{3}{ }^{-4}$ [33]. At $\mathrm{pH} 4-5$, most of the carbonate presents in sea and ground water is destroyed and uranyl ions set free to form complexes with other ions and get sorbed on PAC to give quantitative sorption within 10 minutes. After sorption on PAC, maximum uranium recovery was obtained by leaching with $0.8 \mathrm{~N}$ nitric acid. These investigations are presented in this paper. 


\section{METHODS AND MATERIAL}

\section{A. Instrumentation}

1. LED (Light Emitting Diode), Fluorimeter, LF-2 supplied by Quantalase Enterprises Private Limited, India was used for uranium measurements at $\mathrm{ppb}$ levels by the present preconcentration method. The instrumental specifications are given in Table 1.

2. Pellet Fluorimeter (ECIL make, India) was used for the measurement of uranium in sufficiently preconcentrated water samples by treating with aluminum nitrate and solvent extraction with ethyl acetate. A suitable aliquot was evaporated to dryness in platinum blanks, fused with flux, and fluorescence measurements are taken.

\section{B. Reagents}

1. Powdered Activated Carbon (PAC), Sd-Fine chemicals, commercially available was used. PAC was purified by boiling with $1.6 \mathrm{M} \mathrm{HNO3}$ to remove impurities. Details of PAC are given in Table 2.

2. Tetra Sodium Pyrophosphate deca hydrate, Emparta, ACS (Merck Specialties Private Limited) was used.

3. Nitric acid (Assay: 70\%, ExcelaR, Qualigens, Fisher Scientific) was used.

4.Ortho Phosphoric acid (Assay: 88\%, ExcelaR, Qualigens, Fisher Scientific) was used for $\mathrm{pH}$ adjustment.

5. Deionized water was used throughout this work.

6. Tetra Sodium Pyrophosphate buffer: 5 gm of Tetra Sodium Pyrophosphate was dissolved in $100 \mathrm{~mL}$ distilled water and the $\mathrm{pH}$ adjusted to 7 to 7.5 using dilute phosphoric acid. This solution is referred as buffer in the text and acts as a fluorescence enhancing reagent.

\section{Standard Solutions}

1. Standard stock solution of uranium (VI) of $1 \mathrm{mg} /$ $\mathrm{mL}$ was prepared by dissolving an appropriate quantity of $\mathrm{U}_{3} \mathrm{O}_{8}$ (Uranyl nitrate $\mathrm{UO}_{2}\left(\mathrm{NO}_{3}\right)_{2} 6 \mathrm{H}_{2} \mathrm{O}$;
Assay: 98-102\%, GR Grade (Loba Chemie) was ignited to $850^{\circ} \mathrm{C}$ in a furnace to form $\mathrm{U}_{3} \mathrm{O}_{8}$ in a minimum amount of nitric acid, and then further diluted to 1 litre with quartz distilled water.

2. Working standard solutions of $\mathrm{U}_{3} \mathrm{O}_{8}, 1 \mathrm{~mL}=100 \mu \mathrm{g}$, $1 \mathrm{~mL}=10 \mu \mathrm{g}, \quad 1 \mathrm{~mL}=1 \mu \mathrm{g}$, were prepared fresh by appropriately diluting the standard stock solution.

3. Calibration standards of $\mathrm{U}_{3} \mathrm{O}_{8}, 1 \mathrm{ng} / \mathrm{mL}, 2 \mathrm{ng} / \mathrm{mL}$, $10 \mathrm{ng} / \mathrm{mL}, 20 \mathrm{ng} / \mathrm{mL}, 50 \mathrm{ng} / \mathrm{mL}$ and $100 \mathrm{ng} / \mathrm{mL}$ were prepared in $50 \mathrm{~mL}$ volumetric flasks by adding $4 \mathrm{~mL}$ of Tetra Sodium Pyro phosphate buffer.

\section{Collection of Ground-water and Sea-water samples}

From various parts of Andhra Pradesh, ground water from bore wells, brine and sea water samples were collected in polythene bottles after washing with deionized water followed by drying before collection. These samples were filtered through 0.45 micron Whatman filter paper and finally acidified with nitric acid to a pH at approximately 2 .

\section{E. Pre concentration Procedure}

Two liters of sea water or brine water or ground water was taken and the $\mathrm{pH}$ adjusted to $4-5$ with dilute $\mathrm{HCl}$. Then $0.5 \mathrm{~g}$ PAC was added and left standing for 10 minutes with occasional stirring, and the solution filtered using a 540 Whatman filter paper. Uranium sorbed on PAC is recovered by leaching with $0.8 \mathrm{~N}$ nitric acid. The ground-water samples were filtered through Whatman 540 filter paper, washed with $0.8 \mathrm{~N} \mathrm{HNO}_{3}$, the solution dried on a water bath to evaporate the acid and then made up to $10 \mathrm{~mL}$ volume by adding $1 \mathrm{~mL}$ buffer. Uranium was determined by the LED fluorimetric technique. In case of sea water, the volume was made up to $10 \mathrm{~mL}$ after evaporation of the acid on a water bath. It was then further diluted 10 times prior to uranium determination by LED fluorimetry after addition of 1 $\mathrm{mL}$ buffer. 


\section{RESULTS AND DISCUSSION}

To keep blank values very low, PAC (purified by boiling with $1.6 \mathrm{M} \mathrm{HNO3),} \mathrm{acids} \mathrm{and} \mathrm{water} \mathrm{were}$ purified as the uranium concentration is at nano gram levels in water. In the present investigations, the sorption of uranium from the aqueous solutions on PAC was carried out at 10 nano gram level. Various experimental parameters, such as like effect of $\mathrm{pH}$, quantity of PAC, time of contact, effect of volume, were studied using ground-water spiked with 10 $\mathrm{ng} / \mathrm{mL}$ uranium and the optimized parameters were applied to sea-water and brine-water samples.

\section{A. Effect of $\mathrm{pH}$}

Studies were carried out from $\mathrm{pH} 1$ to 10 , to optimize the $\mathrm{pH}$ for the quantitative sorption of uranium on $0.5 \mathrm{~g}$ of PAC for one liter of natural ground-water doped with $10 \mu \mathrm{g}$ uranium with contact time of 2 hours. Uranium from the aqueous solutions is sorbed quantitatively (>95\%) on PAC at $\mathrm{pH} 4$ to 5 . At $\mathrm{pH} 3$ and $\mathrm{pH} 6$, uranium sorption was $81 \%$ and $85 \%$, respectively; at $\mathrm{pH} 2$ and $\mathrm{pH} 7$ uranium sorption was 50\%; at $\mathrm{pH} 1$ and $\mathrm{pH} 9$, sorption was coming down to $20 \%$ and $16 \%$, respectively. At pH 10 it is further comes down to $10 \%$. The results are shown in Figure 1. The percent sorption of uranium decreased drastically above $\mathrm{pH} 6$ is due to the presence of carbonate and bicarbonate ions which affect the uranium sorption.

\section{B. Effect of Quantity of PAC}

To optimize the quantity of PAC for quantitative sorption of uranium, at $\mathrm{pH} 4$ to5 with 1 litre of natural ground water doped with $10 \mu \mathrm{g}$ uranium which corresponds to $10 \mathrm{ng} / \mathrm{mL}$, with a contact time of 2 hours, studies were carried out with 0.1 to $2.0 \mathrm{~g}$ of PAC. The sorption of uranium gets increased from 0.1 to $0.5 \mathrm{~g}$ of PAC, and remains almost constant even up to $2.0 \mathrm{~g}$. The results are shown in Table 3 . When $0.1 \mathrm{~g}$ of PAC was used, the recovery of uranium was around $88 \%$. This indicates that PAC may be insufficient for complete sorption of uranium. Hence, keeping in view the maximum concentration of uranium at $5000 \mathrm{ppb}$ in ground-water and $3 \mathrm{ppb}$ in sea-water, the PAC quantity was fixed at $0.5 \mathrm{~g}$ for 1 liter volume. For calcium-rich and magnesium-rich ground-water samples containing very low concentrations of uranium, it may be necessary to start with a large volume of sample solution to achieve a high enrichment factor. In such cases, the quantity of PAC may be increased accordingly.

\section{Effect of Contact Time}

The quantitative sorption (>95\%) of uranium from the aqueous phase onto a solid phase, i.e. PAC, depends on the contact time of the two phases. Studies were carried out at $\mathrm{pH} 4$ to 5 with one liter of natural ground-water doped with $10 \mu \mathrm{g}$ of uranium using 0.5 $\mathrm{g}$ of PAC up to 2 hours right from instantaneous filtration. The results listed in Table 4 indicate that sorption of uranium is $>95 \%$ within the first 10 minutes of contact time of the two phases. At contact time of 10 minutes and above, it was found experimentally that highly reproducible results were obtained (see Table 4).

\section{Effect of Volume}

Samples having high concentrations of chloride and TDS with an uranium concentration $<1$ ppb requires simultaneous separation and pre concentration of uranium from the rest of the matrix. The pre concentration factor should be high enough to raise the uranium concentration several times above the detection limits of the LED fluorimeter in order to have highly reliable and reproducible values. Also, with the high enrichment factor, the effect of procedural blank is negligible. Thus, in order to see the effect of volume, studies were carried out with varying volumes of natural ground water from 100 $\mathrm{mL}$ to $2000 \mathrm{~mL}$ at $\mathrm{pH} 4$ to 5 with $0.5 \mathrm{~g}$ of PAC and a contact time of 10 minutes. The results obtained are 
given in Table 5. Recoveries were found to be quantitative, indicating that the sample volume can be increased up to 2 liters with the optimized parameters.

\section{E. Desorption Studies}

Either dry ashing of carbon or leaching with mineral acids can be used for desorption of uranium from PAC. Since dry ashing is a time-consuming procedure, the authors studied the desorption using mineral acids. The most common mineral acids used are hydrochloric acid, nitric acid, sulfuric acid and phosphoric acid. Phosphoric acid and sulfuric acid are unsuitable as desorbing agents for uranium as their boiling point is very high and hence, the complete removal of acids by evaporation before determination of uranium by LED fluorimetry is a tedious process. As chlorides of $\mathrm{HCl}$ act as quencher during fluorescence measurement of uranium, nitric acid was preferred for desorption of uranium from PAC and the recovery was more than $95 \%$. In order to optimize the concentration of nitric acid, studies were carried out with various concentrations of $\mathrm{HNO}_{3}$ from 0.2 to $0.8 \mathrm{~N} \mathrm{HNO}_{3}$. With $0.8 \mathrm{~N}$ nitric acid (5\%), uranium recovery was more than $95 \%$, hence $0.8 \mathrm{~N}$ nitric acid was fixed as the optimum parameter for desorption of uranium from PAC. The results are given in Table 6.

\section{F. Effect of Other Ions}

The effect of various anions and cations on uranium sorption was also carried out in ground water samples of varying TDS. The results in Table 7 show that the effect of anions and cations on uranium sorption is negligible.

\section{G. Repeatability of the Method}

Experiments were conducted to test the repeatability of the method by taking 2 liters of four ground water samples and one sea water sample in quadruplicate. The procedure followed for the pre-concentration was same as the described earlier and the RSD of the method varied from 6 to $14 \%$.

\section{H. Accuracy of the Method}

Due to non-availability of standard sea-water, brinewater and ground-water samples in our laboratory, the accuracy of the present method was checked by spiking one liter of natural and synthetic groundwater and sea-water after treating them with $0.5 \mathrm{~g}$ of fresh PAC at pH 4 to 5 to remove more than $99 \%$ of uranium present in the samples. Synthetic groundwater and sea-water samples were prepared by dissolving appropriate concentrations of $\mathrm{Na}, \mathrm{K}, \mathrm{Ca}$, $\mathrm{Mg}, \mathrm{Cl}^{-}, \mathrm{HCO}_{3}^{-}, \mathrm{SO}_{4}^{-2}$, etc, in ultra pure deionized water. These natural and synthetic ground-water and sea-water samples were spiked with $10 \mathrm{ng}, 100 \mathrm{ng}$, $1000 \mathrm{ng}$, and 10,000 ng of uranium corresponding to $0.01 \mathrm{ng}, 0.1 \mathrm{ng}, 1 \mathrm{ng}$ and $10 \mathrm{ng}$ of uranium, respectively. The percent recovery was more than $95 \%$ and the results are given in Table 8 . This indicates that the method is accurate, reliable, and independent of matrix effect on the sorption of uranium.

\section{J. Application to Sea-water, Brine-water and Ground- water Containing $\mathrm{U}<1 \mathrm{ppb}$}

Sea-water contains high concentrations of chloride, sodium, calcium, sulphate, and magnesium ions along with uranium at the ppb level. Uranium determination cannot be carried out directly by LED fluorimetry, and requires separation from the matrix to eliminate the chloride interference and the effect of high concentration of calcium and magnesium salts which form insoluble phosphates. By the present method, uranium can be easily determined by LED fluorimetry after its separation, unlike Pellet fluorimetry which involves use of salting out agent, corrosive solvent, flux, platinum blanks, furnace, and lengthy procedures.

Two litres of sea-water and brine-water samples were processed by the procedure described above, and the 
uranium was determined by LED fluorimetry. The values obtained by LED fluorimetric technique are comparable with the pellet fluorimetric technique and the results are given in Table 9.

In some of the areas where uranium in ground water is less than $1 \mathrm{ppb}$ (one nano gram per milliliter) goes undetected due to the non-availability of quantifiable uranium values. But the ground water samples require to be analyzed down to $0.01 \mathrm{ppb}$ for meaningful interpretation of data of the specific areas, which demands pre-concentration prior to analysis. Even the determination of uranium at very low levels, requires a separation of the precipitating elements such as $\mathrm{Ca}, \mathrm{Mg}$, and the quenching elements such as $\mathrm{Fe}, \mathrm{Mn}, \mathrm{Cl}-$. As the PAC is non-selective to alkali and alkaline earth salts, the majority of calcium and magnesium salts are left behind in the solution and uranium gets sorbed selectively onto PAC. Hence, the present preconcentration method is applied to some of the ground water samples having uranium concentrations of $<1 \mathrm{ppb}$ and with varying TDS. By this method, the uranium values obtained by LED fluorimetry are compared with Pellet fluorimetric values and the results are comparable with each other as seen in Table 7.

The high TDS water samples containing $0.01 \mathrm{ng} / \mathrm{mL}$ of uranium are pre concentrated to $10 \mathrm{~mL}$ from two liter volume (enrichment factor of 200) would contain $20 \mathrm{ng} / \mathrm{mL}$ in the final volume of $10 \mathrm{~mL}$, which corresponds to $2 \mathrm{ng} / \mathrm{mL}$. The $2 \mathrm{ng} / \mathrm{mL}$ can be easily determined by LED fluorimetry, and the total procedural blank solution corresponds to $10 \%$ of the uranium present in the two liters of ground-water samples. Hence, samples containing $0.01 \mathrm{ng} / \mathrm{mL}$ of uranium can easily be analyzed by the present method with an enrichment factor of 200.

\section{K. Sorption Mechanism of Uranium on PAC}

The sorption of uranium can be attributed to physisorption/chemisorption. The $-\mathrm{OH},-\mathrm{COOH}$ groups on PAC were chemically bonded with uranyl ion. The mechanism of sorption of uranium on PAC may be from both ion exchange and electron donating acceptor complexation reactions at the edge sites. At $\mathrm{pH} 4$ to 5 , PAC has a positive surface charge where the uranium removal from the solution takes its maximum value. The maximum loading of uranium ions (load factor) on PAC is 10 milligram per gram. The manuscript covers the application of PAC for removal of uranium from ground-water and sea-water, and at the same time preconcentrates and estimates low concentrations of uranium in water. The detailed systematic studies for the sorption mechanism of surface analysis, etc., will be part of a separate research paper and will be submitted later.

\section{CONCLUSION}

The present method of separation and preconcentration of uranium from sea-water, brinewater, and ground-water containing high calcium, sodium, magnesium, chloride, and other major cations and anions, is simple. The method involves only the addition of powdered activated carbon (PAC) which has a high adsorption capacity of 10 milligram of uranium per gram of $\mathrm{PAC}$, at $\mathrm{pH} 4$ to 5 , and filtering PAC containing uranium after 10 minutes. The uranium from PAC is recovered with $0.8 \mathrm{~N}$ nitric acid and determined by the LED fluorimetric technique. The method could be applied to water samples containing uranium at concentrations of $<1 \mathrm{ppb}$, and the quantitative data obtained are useful in delineating anomalous zones favorable to the presence of uranium. In the absence of such data, areas containing uranium, go uninterpreted and hence these data are meaningful and helps in identifying the concealed deposits. The determination of uranium using the proposed method 
is possible in the presence of high calcium and hence no special chemistry is needed to separate calcium and other matrix elements. Since the reported fluorescence enhancing reagents have limitations with respect to high calcium, magnesium, chloride, and other TDS in the samples, the method is highly useful for these types of samples. The RSD of the method varied from $\pm 6 \%$ to $14 \%$. The method is accurate, reliable and the values are in close agreement with reported pre-concentration methods (pellet fluorimetric method). The method can be applied in field laboratory studies as well as for the removal of uranium from potable water and industrial waste discharges of the nuclear industry.

\section{ACKNOWLEDGEMENTS}

The authors are thankful to Shri G. B. Joshi, Additional Director (R\&D) for his encouragement to carry out the research work. The authors are thankful to Shri L. K. Nanda, Director, AMD, for his keen interest in $\mathrm{R} \& \mathrm{D}$ work and giving permission to publish this paper.

\section{REFERENCES}

[1] Simona Regenspurg, Dieter Schild, Thorsten Schafer, Florian Huber, and Maria E. Malmstrom, Applied Geochemistry 24(9), 1617 (2009).

[2] N. V. Suc, and T. T. Bich, Radiochim. Acta. 101, 621 (2013).

[3] A. R. Byne, and L. Benedik, Inorg. Anal. Chem. 69, 996 (1997).

[4] M. Konstantinou, and L. Pashalidis, Mediterranean Marine Science 5(1), 55 (2004).

[5] Miura, Tsutomu, Morimoto, Takao, Hayano, Kazuhiko, Kishimoto, Takeshi, and Bunseki Kagaku, Japan Analyst 49(4), 245 (2000).

[6] Juracir S. Santos, Leonardo S.G. Teixeiraa, Walter N.L. dos Santos, Valfredo A. Lemos, Jose
M. Godoy, and Sérgio L.C. Ferreiraa, Analytica Chimica Acta 674 (2-3), 143 (2010).

[7] J. R. Wood, G. A. Gill, L. Kuo, J. E. Strivens, and K. Choe, Ind. Eng. Chem. Res. 55, 4344 (2016).

[8] J. C. Robbins, CIM. Bull. 71, 61 (1978).

[9] E. Singer, and J. Marecek, J. Anal.Chem. 196, 321 (1987).

[10] B. K. Balaji, G. Mishra, and Bincy Cyriac, EARFAM 9, 99 (1996).

[11] Chiu L. Chou and John D. Moffatt, Fresenius J Anal Chem 368, 59 (2000).

[12] P. G. Jaison, Vijay M. Telmore, Pranaw Kumar, and Suresh K. Aggarwal, Journal of Chromatographic Science 49, 657 (2011).

[13] K. Kato, M. Ito, and K. Watanabe, Fresen. J. Anal. Chem. 366, 54 (2000).

[14] Magdi Khalifa, Separation Science and Technology 33(14), 2123 (2008).

[15] P. G. Jaison, V. M. Telmore, Pranaw Kumar, and S. K. Aggarwal, Journal of Chromatographic Science 49, 72 (2011).

[16] N. Nashine, and R.K. Mishra, Analyst 120, 197 (1995).

[17] P. K. Tarafder, L. Kunkal, P. Murugesan, and D. P. S. Rathore, Journal of Radioanalytical and Nuclear Chemistry 253, 135 (2002).

[18] J. Chang, Z.J. Li, and M. Li, Int. J. Environ. Anal. Chem. 88, 583 (2008).

[19] Sukanta Maity, S. K. Sahu and G. G. Pandit, Journal of Radioanalytical and Nuclear Chemistry 303 (1), 33 (2015).

[20] Leela Gopal, M. A. Nayeem, and D. S. R. Murthy, EARFAM 17, 31 (2007).

[21] Bincy Cyriac and B. K. Balaji, Microchimica Acta 17, 33 (2010).

[22] B. Sunilkumar, and G. Chakrapani, Journal of Radioanalytical and Nuclear Chemistry 302 (3), 1489 (2014).

[23] F.Z. El Aamrani, L. Duro, J. de Pablo, and J. Bruno, Appl. Geochem. 17 (4), 399 (2002). 
[24] H. Parab, S. Joshi, N. Shenoy, R. Verma, A. Lali, and M. Sudersanan, Bioresource Technol. 96 (11), 1241 (2005).

[25] T.E. Payne, J.A. Davis, G.R. Lumpkin, R. Chisari, and T.D. Waite, Appl. Clay. Sci. 26(1-4), 151 (2004).

[26] M. Kalin, W.N. Wheeler, and G. Meinrath, J. Environ. Radioact. 78(2), 151 (2004).

[27] T. Missara, M. Garcia-Gutierrez, and C. Maffiotte, J. Colloid Interface Sci. 260(2), 291 (2003).

[28] Zhang Xiao-teng, Jiang Dong-mei, Xiao Yi-qun, Chen Jun-chang, Hao Shuai, and Xia Liang-shu, Journal of Chemistry Article ID 6409504, 1 (2019).

[29] A. Mellah, Z. Chegrouche, and M. Barkat, Journal of colloid and interface science 296, 434 (2006).

[30] M. Karadeniz, C. Kutahyali, and M. Eral, Turkish Journal of Nuclear Sciences 29 (1-2), 19 (2003).

[31] G Chakrapani, Ph.D. thesis, Development of Preconcentration techniques for the estimation of trace and ultra trace elements and their application to geological and Hydro geochemical samples, Bangalore University, 1996 (unpublished thesis).

[32] Leela Gopal, and G. Chakrapani, Symposium proceedings of 'Emerging Trends in Analytical Chemistry (ETAC-2016)', 182 (2016).

[33] K. Saito, and T. J. Miyauchi, Nucli Sci Technol. 19, 145 (1982).

\section{Cite this article as :}

Leela Gopal, V. V. Hanuman, G. Chakrapani, "Separation cum Pre-concentration technique for determination of Uranium in sea, brine and ground water at nano to sub nanogram levels", International Journal of Scientific Research in Science and Technology (IJSRST), Online ISSN : 2395-602X, Print ISSN : 2395-6011, Volume 7 Issue 2, pp. 302-312, March-April 2020. Available at doi : https://doi.org/10.32628/IJSRST207246 Journal URL : http://ijsrst.com/IJSRST207246

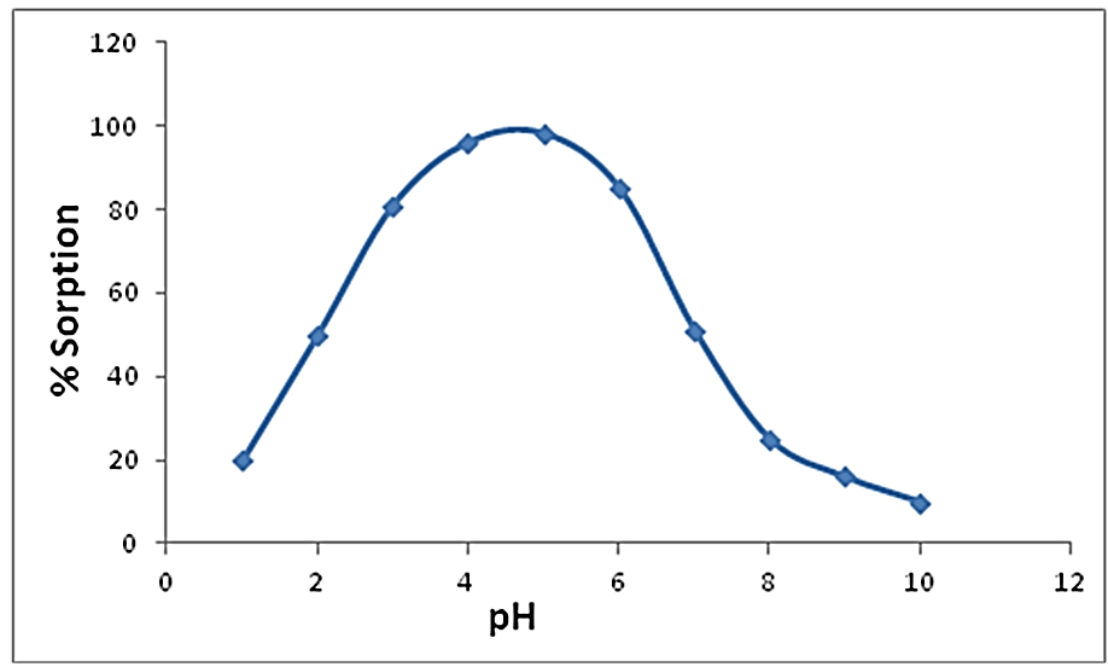

Figure 1 : Effect of $\mathrm{pH}$ on Uranium Sorption

Sample Volume: 1 liter; U added: $10 \mu$ g, PAC: 0.5 G, Contact time: 2 hours 
Table 1 : Specifications of LED (Light Emitting Diode), Fluorimeter, LF-2

\begin{tabular}{|l|l|}
\hline Analytical Technique & Fluorescence of Uranium \\
\hline Element analysed & Uranium in aqueous medium \\
\hline Excitation source & LED ( Light Emitting Diodes) \\
\hline Detector & Photo Multiplier Tube \\
\hline Minimum concentration & 0.2 microgram uranium/ liter i.e. $0.2 \mathrm{ppb}$ \\
\hline Dynamic range & 0.2 to $500 \mathrm{ppb}$ \\
\hline Accuracy & $5 \%$ or $0.05 \mathrm{ppb}$ whichever is larger \\
\hline Reproducibility & Better than $5 \%$ \\
\hline
\end{tabular}

Table 2 : Details of PAC

\begin{tabular}{|l|l|}
\hline Particle size & 300 mesh \\
\hline $\mathrm{pH}$ & 6 to 7.5 \\
\hline $\mathrm{LOD}\left(105^{0} \mathrm{C}\right.$ for 2 hours $)$ & $3 \%$ \\
\hline Ash & $2 \%$ \\
\hline Acid soluble & $0.5 \%$ \\
\hline Phosphate & Negligible \\
\hline Chloride $(\mathrm{Cl})$ & $0.01 \%$ \\
\hline Sulphate $\left(\mathrm{SO}_{4}\right)$ & $0.01 \%$ \\
\hline Iron $(\mathrm{Fe})$ & $0.01 \%$ \\
\hline Zinc $(\mathrm{Zn})$ & $0.001 \%$ \\
\hline
\end{tabular}

Table 3 : Effect of Quantity of PAC

\begin{tabular}{|c|c|}
\hline Quantity of PAC(g) & \%Recovery of Uranium \\
\hline 0.1 & 88 \\
\hline 0.2 & 91 \\
\hline 0.5 & 95 \\
\hline 1.0 & 96 \\
\hline 2.0 & 96 \\
\hline
\end{tabular}

Sample Volume: 1 liter; U added: $10 \mu \mathrm{g}, \mathrm{pH}$ : 4-5, Contact time: 2 hours

Table 4 : Effect of contact time

\begin{tabular}{|c|c|}
\hline Contact time & \%Recovery of Uranium \\
\hline Instantly & 85 \\
\hline $10 \mathrm{mts}$ & 95 \\
\hline $30 \mathrm{mts}$ & 96 \\
\hline $1 \mathrm{hr}$ & 96 \\
\hline $2 \mathrm{hr}$ & 96 \\
\hline
\end{tabular}

Sample Volume: 1 liter; U added: $10 \mu \mathrm{g}$, PAC: 0.5 G, pH: 4-5 
Table 5 : Effect of Volume

\begin{tabular}{|c|c|}
\hline Volume $(\mathrm{mL})$ & \% Recovery of Uranium \\
\hline 100 & 98 \\
\hline 200 & 97 \\
\hline 500 & 98 \\
\hline 1000 & 95 \\
\hline 2000 & 95 \\
\hline
\end{tabular}

U added: $10 \mu \mathrm{g}$, PAC: $0.5 \mathrm{G}$, Contact time: 10 minutes, $\mathrm{pH}$ : 4-5

Table 6 : Desorption of U from PAC

\begin{tabular}{|c|c|}
\hline Conc. of $\mathrm{HNO}_{3}$ & \% Desorption \\
\hline $\mathrm{pH}-2$ & 10 \\
\hline $0.2 \mathrm{~N} \mathrm{HNO}_{3}$ & 80 \\
\hline $0.3 \mathrm{NHNO}_{3}$ & 82 \\
\hline $0.5 \mathrm{NHNO}_{3}$ & 84 \\
\hline $0.8 \mathrm{NHNO}_{3}$ & 99 \\
\hline
\end{tabular}

Sample Volume: 1 liter, U added: $10 \mu$ g, PAC: 0.5 G, Contact time: 10 minutes, pH: 4-5

Table 7 : Application to Ground-water, Sea-water and Brine-water samples

\begin{tabular}{|r|l|c|c|c|c|c|c|c|c|c|c|}
\hline $\begin{array}{r}\text { S. } \\
\text { No }\end{array}$ & Sample No. & $\begin{array}{c}\mathrm{TDS} \\
\mathrm{mg} / \mathrm{L}\end{array}$ & $\begin{array}{c}\mathrm{HCO}^{-} \\
\mathrm{mg} / \mathrm{L}\end{array}$ & $\begin{array}{c}\mathrm{Cl}^{-} \\
\mathrm{mg} / \mathrm{L}\end{array}$ & $\begin{array}{c}\mathrm{SO}^{-2} \\
\mathrm{mg} / \mathrm{L}\end{array}$ & $\begin{array}{c}\mathrm{Na}^{+} \\
\mathrm{mg} / \mathrm{L}\end{array}$ & $\begin{array}{c}\mathrm{K}^{+} \\
\mathrm{mg} / \mathrm{L}\end{array}$ & $\begin{array}{c}\mathrm{Ca}^{+2} \\
\mathrm{mg} / \mathrm{L}\end{array}$ & $\begin{array}{l}\mathrm{Mg}^{+2} \\
\mathrm{mg} / \mathrm{L}\end{array}$ & $\begin{array}{l}\text { U(ppb) by } \\
\text { Present } \\
\text { Method }\end{array}$ & $\begin{array}{l}\text { U(ppb) } \\
\text { By Pellet } \\
\text { Fluorimetry }\end{array}$ \\
\hline 1 & AMD-1 & 540 & 426 & 99 & 73 & 80 & 10 & 88 & 27 & $0.01 \pm 0.001$ & $<1$ \\
\hline 2 & AMD-2 & 620 & 335 & 103 & 50 & 104 & 7 & 60 & 37 & $0.03 \pm 0.003$ & $<1$ \\
\hline 3 & AMD-3 & 970 & 405 & 174 & 37 & 104 & 2 & 40 & 67 & $0.05 \pm 0.004$ & $<1$ \\
\hline 4 & AMD-4 & 1100 & 148 & 298 & 104 & 53 & 3 & 90 & 79 & $0.02 \pm 0.002$ & $<1$ \\
\hline 5 & AMD-5 & 1250 & 527 & 249 & 68 & 243 & 1 & 40 & 63 & $0.05 \pm 0.006$ & $<1$ \\
\hline 6 & AMD-6 & 1450 & 313 & 241 & 130 & 150 & 19 & 60 & 67 & $0.1 \pm 0.006$ & $<1$ \\
\hline 7 & AMD-7 & 1550 & 299 & 383 & 170 & 251 & 18 & 70 & 71 & $0.1 \pm 0.008$ & $<1$ \\
\hline 8 & AMD-8 & 1740 & 412 & 423 & 163 & 216 & 81 & 80 & 97 & $0.04 \pm 0.005$ & $<1$ \\
\hline 9 & AMD-9 & 2100 & 750 & 491 & 236 & 364 & 155 & 120 & 79 & $0.5 \pm 0.03$ & $<1$ \\
\hline 10 & AMD-10 & 2800 & 663 & 790 & 370 & 650 & 2 & 135 & 49 & $0.5 \pm 0.04$ & $<1$ \\
\hline 11 & AMD-SW-1 & 34000 & 136 & 18250 & 2569 & 10200 & 265 & 355 & 1250 & $3.1 \pm 0.2$ & 3 \\
\hline 12 & AMD-SW-2 & 35000 & 145 & 19353 & 2701 & 10752 & 390 & 416 & 1295 & $2.9 \pm 0.2$ & 2 \\
\hline 13 & AMD-BW- & 85000 & 532 & 44380 & 6000 & 17950 & 6300 & 700 & 38300 & $5.0 \pm 0.3$ & 4 \\
\hline 14 & & & & & & & & & & 2 \\
\hline
\end{tabular}

Sample Volume: 2 liter, U added: $10 \mu \mathrm{g}$, PAC: 0.5 G, Contact time: 10 minutes, pH: 4-5, SW- Sea-water, BW - Brine-water 
Table 8 : Evaluation of accuracy of the present method

\begin{tabular}{|c|c|c|c|c|}
\hline Water Type & $\begin{array}{c}\text { U ( in ng) } \\
\text { present in } \\
\text { sample }\end{array}$ & $\begin{array}{c}\text { U added } \\
\text { (in ng) } \\
\text { in 1000mL sample }\end{array}$ & $\begin{array}{c}\text { U found } \\
\text { ( in ng) } \\
\text { in 10mL sample }\end{array}$ & \% Recovery of U \\
\hline QDW & $<0.5$ & 10000 & 9650 & 96 \\
& & 1000 & 972 & 97 \\
& & 100 & 96 & 96 \\
\hline NGW-2 & $<0.5$ & 10 & 9.2 & 97 \\
& & 1000 & 9745 & 96 \\
& & 100 & 965 & 94 \\
& 1 & 10 & 94 & 94 \\
\hline NGW-4 & & 10000 & 9.4 & 98 \\
& & 100 & 9820 & 95 \\
& & 10 & 93 & 91 \\
\hline SGW & $<0.5$ & 10000 & 10 & 96 \\
& & 1000 & 9625 & 94 \\
& & 100 & 945 & 93 \\
\hline NSW & 3 & 10 & 93 & 95 \\
& & 5000 & 9 & 95 \\
\hline SSW & 3 & 1000 & 9750 & 97 \\
\hline & & 3000 & 953 & 96 \\
\hline
\end{tabular}

QDW: Quartz Distilled Water

NGW-2: Natural Ground water with high TDS

NGW-4: Natural Ground water with high $\mathrm{Ca}, \mathrm{Mg}, \mathrm{Cl}$ and $\mathrm{SO}_{4}$

SGW: Synthetic Ground water with high $\mathrm{Ca}, \mathrm{Mg}, \mathrm{Cl}$ and $\mathrm{SO}_{4}$

NSW: Natural sea water

SSW: Synthetic sea water

Table 9: Application to sea water and brine samples of high TDS

\begin{tabular}{|c|c|c|c|}
\hline S. No & Sample No. & $\begin{array}{c}\mathrm{U}(\mathrm{ppb}) \text { by } \\
\text { Present Method } \\
\text { Enrichment factor is } 200\end{array}$ & $\begin{array}{c}\mathrm{U}(\mathrm{ppb}) \\
\text { By Pellet } \\
\text { Fluorimetry }\end{array}$ \\
\hline 1 & AMD(SW) & $3.1 \pm 0.2$ & 3 \\
\hline 2 & AMD(SW) & $3.2 \pm 0.3$ & 2 \\
\hline 3 & AMD(SW) & $2.9 \pm 0.2$ & 2 \\
\hline 4 & AMD-(BW) & $5.0 \pm 0.3$ & 4 \\
\hline 5 & AMD-(BW) & $0.5 \pm 0.03$ & $<1$ \\
\hline 6 & AMD-(BW) & $2 \pm 0.2$ & 2 \\
\hline
\end{tabular}

SW-Sea-water, BW - Brine-water 